\title{
Flowing into the unknown: inferred paleodrainages for studying the ichthyofauna of Brazilian coastal rivers
}

\author{
Andréa T. Thomaz ${ }^{1,2}$ and L. Lacey Knowles ${ }^{1}$
}

The eastern coastal basins of Brazil are a series of small and isolated rivers that drain directly into the Atlantic Ocean. During the Pleistocene, sea-level retreat caused by glaciations exposed the continental shelf, resulting in enlarged paleodrainages that connected rivers that are isolated today. Using Geographic Information System (GIS), we infer the distribution of these paleodrainages, and their properties for the east Brazilian coast. Specifically, using elevation/bathymetric data for the largest sea-level retreats during the Pleistocene, the paleodrainages, their area and the number of contemporary basins connected by each palaeodrainage, was inferred. For the 145 inferred paleodrainages, total paleodrainage area is strongly correlated with the contemporary area encompassed by each paleodrainage, as well as with the number of contemporary basins encompassed by a paleodrainage. Differences in the continental shelf exposure along the coast affected the degree of past connectivity among contemporary rivers. With our results freely available, we discuss how paleodrainages have tremendous utility in biological studies, especially in regions with limited geologic data. With respect to the diverse ichthyofauna of the Brazilian coast, and its high endemism, we highlight how the inferred paleodrainages provide a backdrop to test hypotheses about the effect of past riverine connectivity on diversity patterns.

Keywords: Freshwater fishes, Glaciations, Pleistocene, Riverine connections, Sea-level retreat.

As bacias costeiras do leste do Brasil são formadas por uma série de rios pequenos e isolados que drenam diretamente para o Oceano Atlântico. Durante o Pleistoceno, o recuo do nível do mar causado por glaciações expôs a plataforma continental, resultando em paleodrenagens amplas que conectaram rios atualmente isolados. Usando o Sistema de Informações Geográficas (GIS), inferimos a distribuição destas paleodrenagens e suas propriedades ao longo da costa leste do Brasil. Especificamente, utilizando dados de elevação/batimetria para as maiores regressões marinhas do Pleistoceno, inferimos as paleodrenagens, suas áreas e quantas bacias contemporâneas foram conectadas por cada paleodrenagem. Para as 145 paleodrenagens inferidas, uma forte correlação é observada entre a área das paleodrenagens e a área atualmente exposta de cada paleodrenagem, bem como a quantidade de bacias contemporâneas conectadas por uma paleodrenagem. Diferenças na exposição da plataforma continental ao longo da costa afetaram o grau de conectividade passada entre os rios. Com estes resultados publicamente disponíveis, discutimos como as paleodrenagens são extremamente úteis para estudos biológicos, especialmente em regiões com dados geológicos limitados. A respeito da diversa ictiofauna da costa brasileira e seus altos níveis de endemismo, destacamos como estas paleodrenagens fornecem uma base importante para o teste de hipóteses a respeito do efeito da conectividade passada dos rios nos padrões de diversidade biológica.

Palavras-chave: Conexões entre rios, Glaciações, Peixes de água doce, Pleistoceno, Recuo no nível do mar.

\section{Introduction}

With the steep slope of mountain chains isolating the east coast from the inland (e.g., Serra do Mar and Chapada Diamantina; Fig. 1), the eastern Brazilian coastal basins are a series of small and isolated rivers that drain directly into the Atlantic Ocean. As a consequence, freshwater fishes in these coastal basins have evolved in isolation with sporadic dispersal with inland basins of Brazil (Weitzman et al., 1988; Ribeiro, 2006). This biogeographic history is hypothesized to underlie the extraordinary diversity of the region, with current estimates of more than 500 valid species of freshwater fishes (Carvalho TP, pers. comm.; Fricke et al., 2017; Fig. 2 ), many of which are endemics (95\% according to Bizerril, 1994). These estimates span the basins between Laguna dos Patos and Rio São Francisco (i.e., no inland basins), which is currently recognized by six Freshwater Ecoregions: Tramandai-Mampituba (335), Southeastern Mata Atlantica (331), Ribeira de Iguape (330), Fluminense (352), Paraiba do Sul (329) and Northeastern Mata Atlantica (328; Abell

${ }^{1}$ Department of Ecology \& Evolutionary Biology, University of Michigan, Museum of Zoology, 1105 N. University Ave., Ann Arbor - MI, 48109, USA. (ATT) thomaz@umich.edu, Dhttp://orcid.org/0000-0002-9755-2674 (corresponding author), (LLK) knowlesl@umich.edu ${ }^{2}$ Biodiversity Research Centre, University of British Columbia, 2212 Main Mall, Vancouver, BC, Canada V6T 1 Z4 
et al., 2008). However, the coastal drainages are not static. Past connections may have been formed among the isolated rivers as the physionomy of the region shifted during the Pleistocene. In particular, the riverine basins that are isolated today are hypothesized to have become part of larger networks of connected rivers (Weitzman et al., 1988; Dias et al., 2014). That is, the formation of paleodrainages during pronounced sea level changes associated with glacial periods would have provided connections on the exposed continental shelf during sea level retreat (Fleming et al., 1998; Miller et al., 2011).

Although geological data provide invaluable information on how rivers may have been connected in the past, the mechanisms creating these patterns are still not fully understood (Perron et al., 2012). This partially reflects the limited availability of geological data, especially among coastal drainages, and uncertainty because of the complexity of this data (for a summary of geological evidence for coastal and inland basins connections see Ribeiro, 2006). Consequently, biologists have relied upon patterns of biodiversity as a mean for identifying putative connections. For example, a generic river capture is often invoked when drainages share species pools (e.g., Albert, Reis, 2011). However, relying on a pattern based on the ichthyofauna itself to make inferences about riverine connections does not allow for tests of the processes giving rise to the observed pattern (i.e., there is no alternative explanations).

The availability of Geographic Information System (GIS) techniques and freely available datasets, including maps of past and present landscapes, can serve as an independent data source for inferring past connections (e.g., Thomaz et al., 2015; 2017), complementing traditional geologic data (Willett et al., 2014). Specifically, hypothesized connections can be inferred from reconstructions of paleodrainages that would have formed during periods of low sea levels based on bathymetric data. This approach has broad applicability, given the general availability of topographic data. Moreover, it can provide detailed information for contiguous regions, in contrast to geologic data that is often limited to particular regions and given the scarcity of paleochannel data for the coast of Brazil (e.g., Zalán, Oliveira, 2005; Conti, 2009; Conti, Furtado, 2009). Reconstructions based on topographic and bathymetric data for expansive coastlines like Brazil become especially appealing. With differences in the distance separating the eastern coastline from the western mountain slope (e.g., Serra do Mar), as well as the width of the continental shelf (Fig. 1), the properties of paleodrainages along the Brazilian coast may also differ. Likewise, the number of currently isolated basins that became connected during the Pleistocene may also vary along the coast, possibly as a function of the width of the continental shelf.

Here we provide reconstructions of paleodrainages using GIS technologies for the eastern coast of Brazil, and for a few basins in the northeast and south. Together they represent a significant expansion over the information to date, which is limited to a local analysis of paleodrainages (Dias et al., 2014; Thomaz et al., 2015; 2017) and of proposed paleo-connections among a set of specific Brazilian river basins (Baggio et al., 2017; Lima et al., 2017). We also characterize general properties of the inferred paleodrainages, including the geographic area spanned by each paleodrainage and the number of contemporary river basins associated with individual paleodrainages. This information provides insights into not only the distribution of paleodrainages and proposed past connections among the rivers that are isolated today, but also how the structure of paleodrainages differs along the coast. We discuss these findings with reference to their broad utility for studying the Brazilian ichthyofauna, ranging from studies of species distributions and diversity, to tests of how the historical connections may structure the genetic variation of contemporary fish taxa, both of which could lead to more informed conservation strategies.

\section{Material and Methods}

Geographic region. The study area includes all coastal rivers ranging from Baía de Turiaçu drainage in Maranhão State in the northeast to Laguna dos Patos basin on the board with Uruguay in the south, in Rio Grande do Sul State, an area that spans more than 5,000 kilometers $(\mathrm{km})$ of the Brazilian coast. This area was selected based on the coastal and continuous freshwater ecoregions, with the exclusion of the Amazonian tributaries. In terms of freshwater fish diversity, the area is currently divided in 11 freshwater ecoregions: Laguna dos Patos (334), Tramandai-Mampituba (335), Southeastern Mata Atlantica (331), Ribeira de Iguape (330), Fluminense (352), Paraiba do Sul (329), Northeastern Mata Atlantica (328), S. Francisco (327), Northeastern Caatinga \& Coastal Drainages (326), Parnaíba (325) and the eastern portion of Amazonas Estuary \& Coastal Drainages (323; Abell et al., 2008). The study region encompasses hundreds of currently isolated river basins that drain the Atlantic Rainforest and Caatinga biomes (Fig. 1).

Inferring Palaeodrainages. Palaeodrainages and the potential connections between contemporary river basins were estimated with ARCGIS10, using Hydrological tools. Four glaciation periods over the Pleistocene had the largest decreases in sea level: $-123 \mathrm{~m}$ at 434 and $630 \mathrm{kya}$ (thousand years ago), $-119 \mathrm{~m}$ at $18 \mathrm{kya}$, and $-110 \mathrm{~m}$ at $138 \mathrm{kya}$ (Miller et al., 2011). Based on these estimates, we reconstructed paleodrainages for a sea level retreat at $-125 \mathrm{~m}$. Topographic and bathymetric information from the General Bathymetric Chart of the Oceans (GEBCO_2014) was used at 30 arc-second resolution (c.1 km; http://www.gebco.net/), covering from 0 degree latitude north to -40 degrees south, and -30 degrees of longitude east to -60 degrees west.

With a base contour line at $-125 \mathrm{~m}$ created using the Contour tool to estimate the maximum extend of land exposed during Pleistocene, the clipped Digital Elevation Model (DEM) raster map was generated. The Fill tool was applied to the map to remove small imperfections, such as localized 


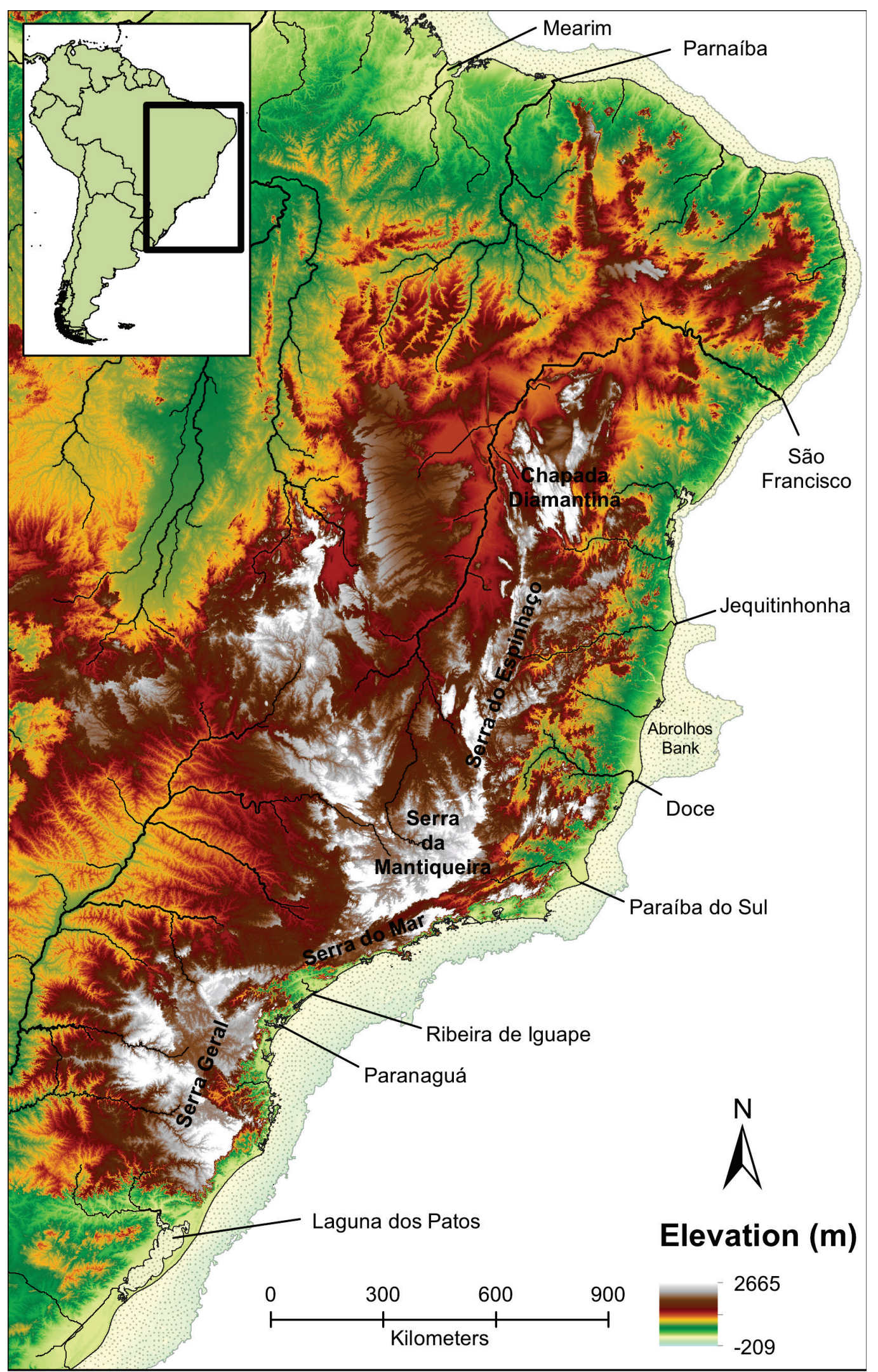

Fig. 1. Map of the Brazilian coast showing main river drainages, bays, lagoons and mountain chains. Elevation and bathymetric profile for the area highlight the isolation of the coastal basins from inland rivers by mountains, including the Serra do Mar and the Chapada Diamantina in the west. Continental shelf exposed during the Pleistocene is marked with the stippled yellow shading. 


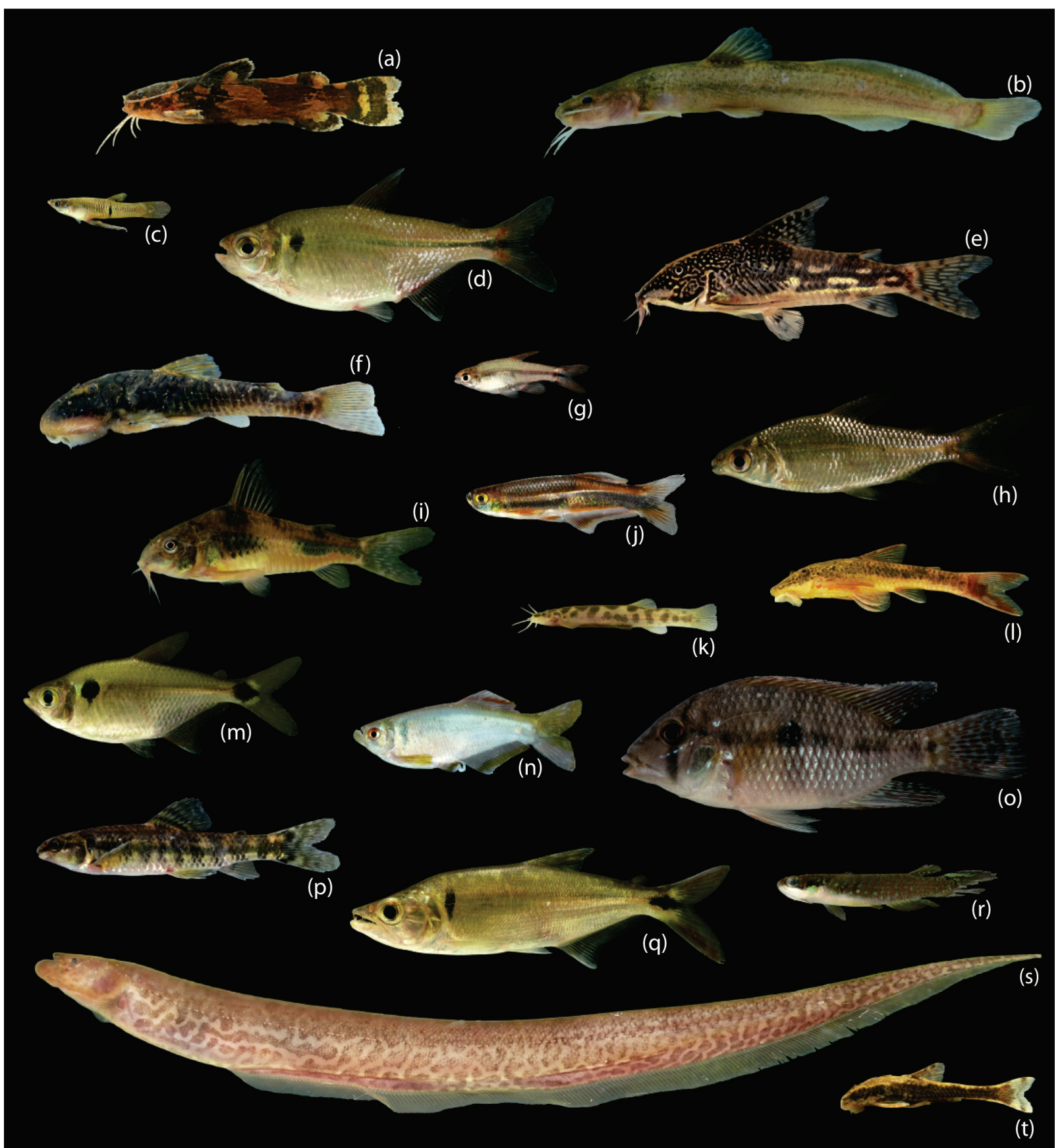

Fig. 2. Samples of some of the freshwater fish species of the Brazilian coastal drainages: a. Microglanis cottoides ((Boulenger, 1891) UFRGS 20930; 43.2 mm SL, standard length), b. Heptapterus sp. (UFRGS 20970; 89.2 mm SL), c. Phalloceros sp. (UFRGS 18596; 22 mm SL), d. Deuterodon singularis Lucena \& Lucena, 1992 (UFRGS 20728; 59.6 mm SL), e. Scleromystax barbatus ((Quoy \& Gaimard, 1824) UFRGS 18832; 65 mm SL), f. Pareiorhaphis splendens ((Bizerril, 1995) UFRGS 20971; $57.4 \mathrm{~mm}$ SL), g. Spintherobolus ankoseion Weitzman \& Malabarba, 1999 (UFRGS 20923; $23.7 \mathrm{~mm}$ SL), h. Cyphocharax santacatarinae ((Fernández-Yépez, 1948) UFRGS 20918; 46.9 mm SL), i. Corydoras ehrhardti Steindachner, 1910 (UFRGS 20938; 50 mm SL), j. Mimagoniates lateralis ((Nichols, 1913) UFRGS 20488; 30.5 mm SL), k. Trichomycterus cf. cubataonis Bizerril, 1994 (UFRGS 20937; 30 mm SL), I. Parotocinclus maculicauda ((Steindachner, 1877) UFRGS 20932; $44.1 \mathrm{mmSL})$, m. Probolodus oyakawai Santos \& Castro, 2014 (UFRGS 18752; 45 mm SL), n. Mimagoniates rheocharis Menezes \& Weitzman, 1990 (UFRGS 20808; 54.2 mm SL), o. Geophagus brasiliensis ((Quoy \& Gaimard, 1824)UFRGS 20919; 72.5 mm SL), p. Characidium pterostictum Gomes, 1947 (UFRGS 18563; 55 mm SL), q. Oligosarcus hepsetus ((Cuvier, 1829) UFRGS 18571; 65 mm SL), r. Atlantirivulus cf. luelingi ((Seegers, 1984) UFRGS 21033; $31.5 \mathrm{~mm} \mathrm{SL),} \mathrm{s.} \mathrm{Gymnotus} \mathrm{pantherinus}$ ((Steindachner, 1908) UFRGS 20928; 186 mm SL), and t. Pseudotothyris ignota Martins, Britski \& Langeani, 2014 (UFRGS 20934; 33.2 mm SL). Photo credits: Tiago P. Carvalho. 
depressions in the DEM, which ensures that flow is maintained among neighbouring cells in the map. Flow direction for each cell in the DEM was determined by its slope using the Flow Direction tool. Based on this flow direction, ridgelines were identified using the Basin tool, and these ridges delineated the inferred paleodrainages.

To infer the past river connections, a raster containing the total number of cells that drain to each specific cell was generated using the Flow accumulation tool. Each cell with more than 100 cells draining into it was used to infer the networks of streams by applying the Stream order function, with river order assignment following Strahler (1957). The riverine raster grids were then converted into vectors using the Stream to Feature tool for generating a map that can be used for analysis, as well as visualization, of inferred paleodrainages.

All files used to infer the paleodrainages and past connections, as well as the digital map of paleodrainages, are freely available at the University of Michigan archive DeepBlue (Thomaz, Knowles, 2018 - dataset: http://dx.doi. org/10.7302/Z2HH6H8P).

Paleodrainage properties. Four properties were calculated for each inferred paleodrainage: (i) total area, (ii) contemporary land area encompassed by each paleodrainage, (iii) area of the continental shelf exposed during the drop in sea level change, and (iv) the number of contemporary river basins encompassed by each paleodrainage. Contemporary basins were estimated following the same methodology described above (excluding basins smaller than $10 \mathrm{~km}^{2}$ ). All summaries of area and river length were calculated using ARCGIS10.

Correlation tests were used to evaluate possible associations between different paleodrainage properties. Specifically, tests between total paleodrainage area with contemporary land area encompassed by each paleodrainage and the number of contemporary basins encompassed by each paleodrainage, as well as the area of the continental shelf of each paleodrainage exposed during sea level change, was performed using the corr function on R (R Core Team, 2017).

\section{Results}

We inferred 145 paleodrainages along the Brazilian coast (Fig. 3), many of which may have provided temporary past connections among 1,034 contemporary river basins that are currently isolated from each other, as well as small basins formed by a single stream. Each paleodrainage is associated with an average of 13 contemporary river basins; however, there was a wide variance in this number across paleodrainages (standard deviation, $\mathrm{SD} \pm 17$; Tab. 1). For example, the paleodrainage that encompassed the most contemporary river basins is the one associated with Laguna dos Patos in southern Brazil, with 166 river basins. This large number of current basins inferred for the Laguna dos Patos paleodrainage reflects in part that the lagoon area was modelled as part of the ocean in the reconstruction. Other paleodrainages also contain a large number of contemporary river basins, which cannot be ascribed to methodological assumptions. This includes Paranaguá estuary and one encompassing the Mearim River basin, each with 55 and 51 contemporary river basins, respectively. In contrast, there were seven paleodrainages that contain a single contemporary river basin. These paleodrainages are represented by a series of small river basins (in the past and present; Tab.1) and restricted to the northeast, occurring primarily in the Northeastern Mata Atlantica freshwater ecoregion.

The inferred paleodrainages have a mean area of 18,369 $\mathrm{km}^{2}(\mathrm{SD}= \pm 67,440)$, in contrast to contemporary basins that have a mean area of $2,246 \mathrm{~km}^{2}(\mathrm{SD}= \pm 24,680)$. However, there is a lot of variation among paleodrainages and contemporary drainages. For example, the São Francisco River, which is the largest contemporary basin, also forms the largest, and similarly sized, paleodrainage (see Tab. 1).

The total area of a paleodrainage is strongly correlated with the contemporary land area encompassed by each paleodrainage $\left(r^{2}=0.99 ; P<0.0001 ;\right.$ Fig. $\left.4 a\right)$, as well as with the number of contemporary basins encompassed by a paleodrainage $\left(r^{2}=0.17 ; P<0.0001 ;\right.$ Fig. $\left.4 \mathrm{~b}\right)$. Moreover, there is a significant, but weak, relationship between the contemporary land area encompassed by each paleodrainage and the area of the continental shelf exposed during the drop in sea level $\left(r^{2}=0.04 ; P=0.01\right.$; Fig. $\left.4 \mathrm{c}\right)$.

A large variance on the width of the exposed continental shelf during the Pleistocene is observed. The continental shelf increased an average of $56 \mathrm{~km}(\mathrm{SD}= \pm 41 \mathrm{~km})$ in width during the largest sea level retreats in the Pleistocene. The width varied from a minimum of $10 \mathrm{~km}$ at Contas River basin up to a maximum of $191 \mathrm{~km} \mathrm{t}$ the Abrolhos bank (Fig. 3).

\section{Discussion}

The paleodrainages we inferred for the coast of Brazil using GIS technologies (Fig. 3) make specific predictions about which contemporary river basins may have experienced connections in the past. Moreover, our analyses also show how the paleodrainages vary in their respective properties (Fig. 4; Tab. 1). As such, the map and the characterizations of the relationship between the present and the past properties of paleodrainages represent an invaluable tool for biological study. Below we highlight noteworthy aspects of the paleodrainages and their distributions, as well as examples of how the results from our study can be applied to studies of the Brazilian ichthyofauna.

Paleodrainages configurations. The large number of inferred paleodrainages is quite interesting in several regards. It highlights that in addition to the notable isolation of many contemporary Brazilian river basins, there was pronounced isolation along the coast in the past as well (Fig. 3), with the properties of the inferred paleodrainages varying considerably (Tab. 1). For example, the distance of the current coast line from the mountains in the west (e.g., the Serra do Mar and Chapada Diamantina; Buckup, 2011) 


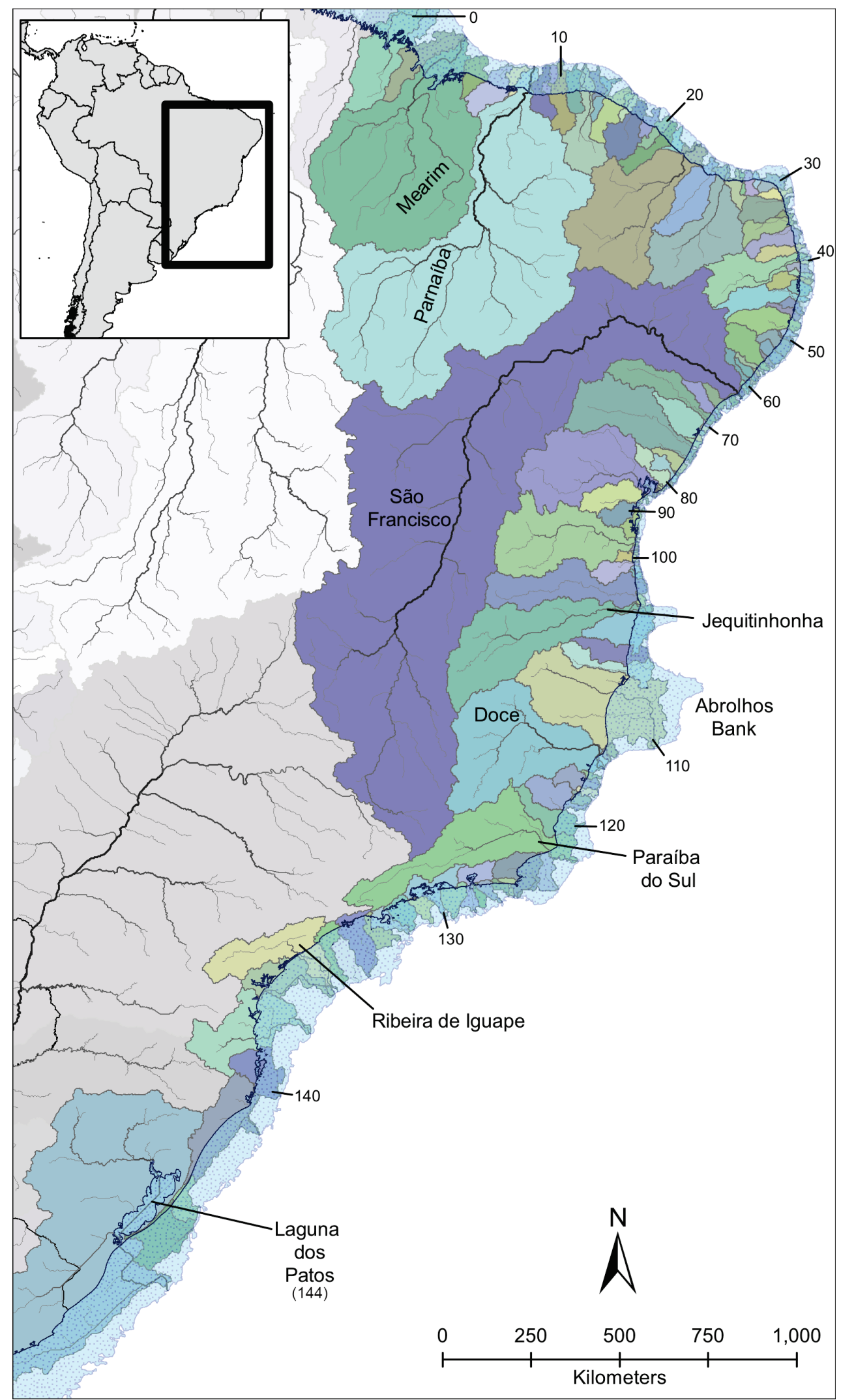

Fig. 3. Map of the 145 palaeodrainages inferred for a sea level retreat of $-125 \mathrm{~m}$ during glacial periods of the Pleistocene; the black line marks the current coastline of Brazil. Both the area that includes the contemporary exposed land area, as well as the area of the continental shelf exposed when sea levels dropped (marked with stippling) is shown for each paleodrainage, with each paleodrainage shown in a different colour. Numbers along the coast indicate the paleodrainage ID on Tab. 1. 
is larger in the north than in the south, while the width of the continental shelf exposed during the Pleistocene was larger in the south. These regional differences in the physical landscape related to the current coastal plain and the past exposure of the coastal shelf produced some clustering in paleodrainage properties, with rivers in the south becoming more connected during the Pleistocene sea level retreat in comparison to the north (Fig. 3). Independent of these regional differences, there is a significant association among paleodrainage properties in general (Fig. 4).

It's important to highlight that the origin and evolution of the Brazilian coastal basins have a long history that started with the Gondwana break-up. Along this time, several geological processes were responsible to form the riverine configuration that we observe today, such as uplifts, faults, fractures and river captures (e.g., Saadi, 1993; Ab'Saber, 1998; Riccomini et al., 2004; Zalán, Oliveira, 2005; Riccomini et al., 2010), features that also shape the distribution of the ichthyofauna in the region (for a summary see Ribeiro, 2006). Two geological mechanisms that potentially remodeled the riverine configuration along the coast that are not taken into account for the Pleistocene reconstructions inferred here are erosion and faults reactivation. Consequently, instances of river captures between adjacent basins associated with such geological phenomena are not represented in our inferred connections based on reconstruction of the paleodrainages. In the future, the application of alternative methods that model these geological processes to infer past connections could also provide valuable insights (Willet et al., 2014). Nevertheless, the concordance between paleodrainages inferences based on application of GIS tool with current topographic information and reconstructions based on geological data from the literature for other portions of the world supports the merit of the approach applied here (Dias et al., 2014). Likewise, a general correspondence between paleodrainage boundaries inferred from the current topography using GIS tools and that structuring of genetic variation also provide independent support for the inferred boundaries of paleodrainages (see Thomaz et al., 2017).

Inferred coastal paleodrainages and studies of the Brazilian ichthyofauna. Thirty years after the proposition by Weitzman et al. (1988) that sea level changes may have influenced speciation and diversification processes of freshwater fishes along the Brazilian coastal drainages, paleodrainage reconstructions are increasing our understanding about the effect of Pleistocene sea level changes on Brazil's freshwater ichthyofauna. For example, fish studies have focused mostly on deeper time scales where dispersal events between coastal and inland basins predate the Pleistocene, and for which there is geological evidence for river captures (e.g., Menezes et al., 2008; Ribeiro, 2006; Roxo et al., 2012, 2014). Yet, without a hypothesis of river connectivity during the Pleistocene, past connections forged by sea level change have not been broadly considered as a factor contributing to observed patterns of freshwater fish
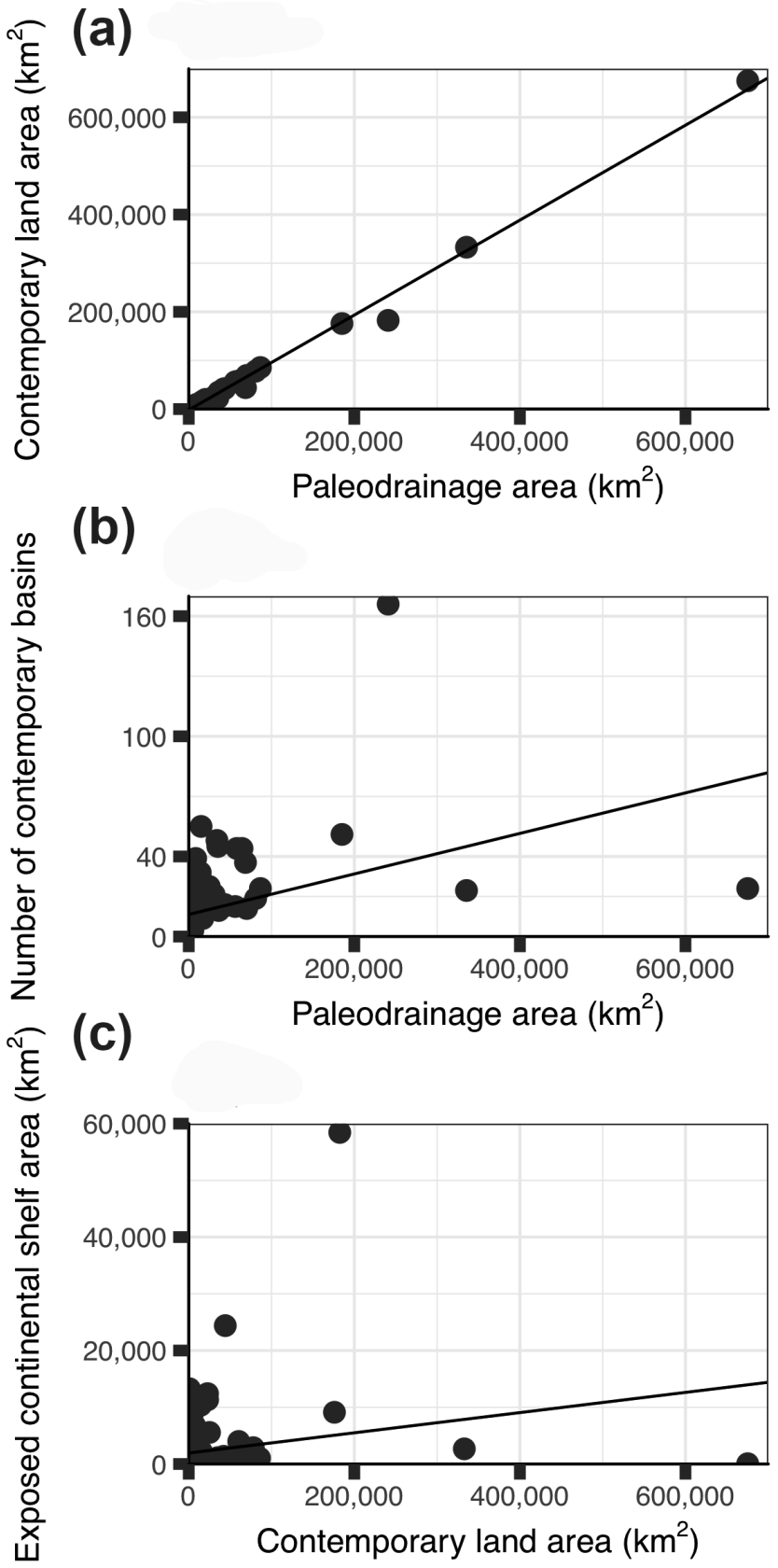

Fig. 4. Results of correlation tests: a. between the paleodrainage total area with contemporary land area encompassed by each paleodrainage $\left(r^{2}=0.99 ; P<0.0001\right)$; b. the number of contemporary basins encompassed by each paleodrainage $\left(r^{2}=0.17 ; P<0.0001\right)$; and c. between the contemporary land area and the area of the continental shelf exposed during the drop in sea level $\left(r^{2}=0.04 ; P=0.01\right)$. Individual values per paleodrainages are given in Tab. 1 .

diversity along the coast (but see Camelier, Zanata, 2014; Carvalho, 2007; Pereira et al., 2013; Torres, Ribeiro, 2008; Zamudio et al., 2009).

The limited study of the role of paleodrainages in structuring the ichthyofauna of Brazil contrasts with studies elsewhere around the globe (Dias et al., 2014). However, 
Tab. 1. Properties calculated for each of the 145 inferred paleodrainages arranged north to south (see Fig. 3 for relative positions along coastline), which includes total paleodrainage area, the contemporary land area encompassed by each paleodrainage, the area of the paleodrainage that was exposed when sea levels dropped (i.e., the corresponding areas of the continental shelf that are submerged today), as well as the number of contemporary basins that was encompassed by each paleodrainage. *Contemporary drainages with areas smaller than $10 \mathrm{~km}^{2}$ were excluded (see 'Material and Methods' section).

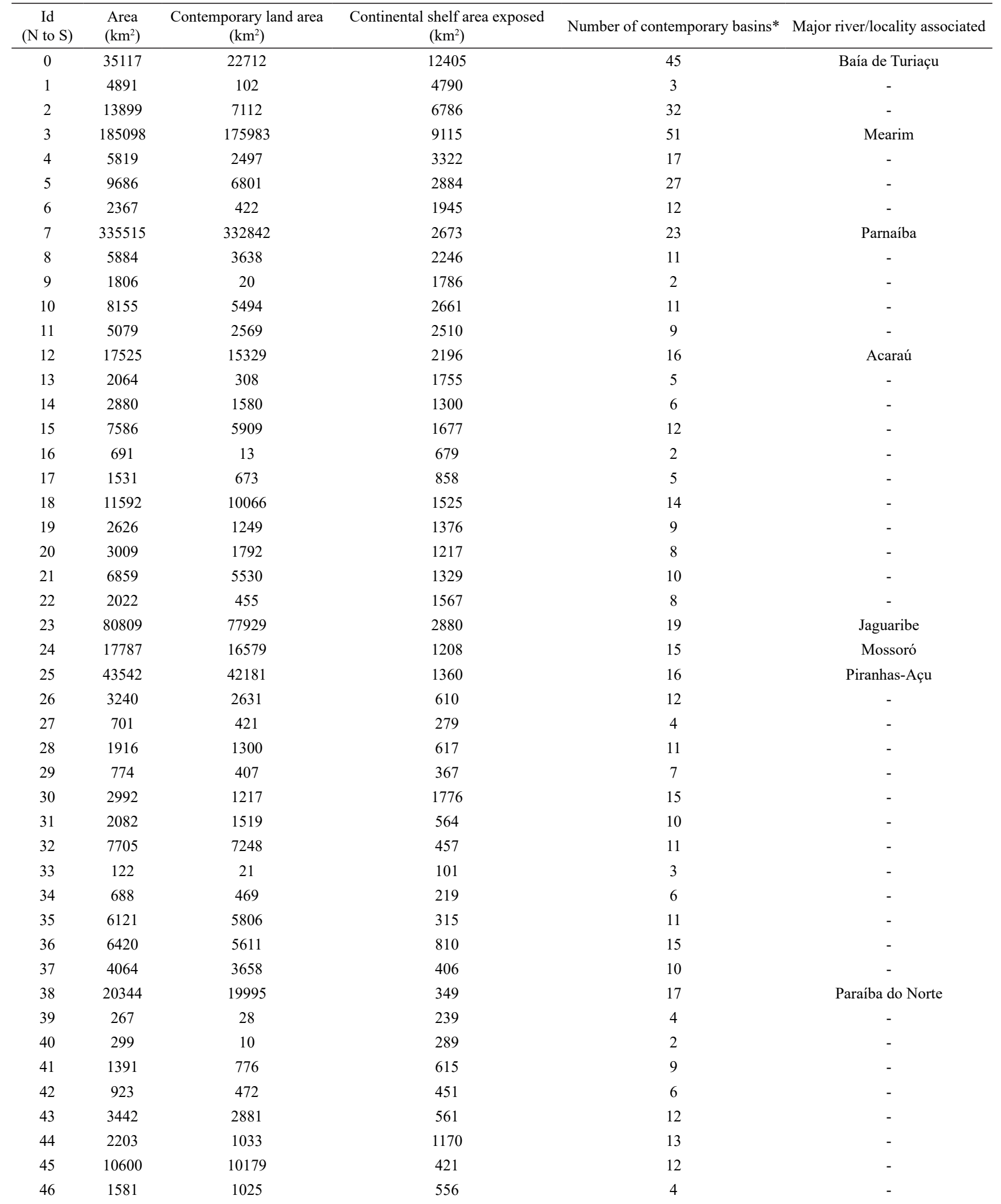


Tab. 1. (continued).

\begin{tabular}{|c|c|c|c|c|c|}
\hline $\begin{array}{c}\mathrm{Id} \\
(\mathrm{N} \text { to } \mathrm{S})\end{array}$ & $\begin{array}{l}\text { Area } \\
\left(\mathrm{km}^{2}\right)\end{array}$ & $\begin{array}{l}\text { Contemporary land area } \\
\qquad\left(\mathrm{km}^{2}\right)\end{array}$ & $\begin{array}{l}\text { Continental shelf area exposed } \\
\qquad\left(\mathrm{km}^{2}\right)\end{array}$ & Number of contemporary basins* & Major river/locality associated \\
\hline 47 & 1717 & 1228 & 488 & 8 & - \\
\hline 48 & 9904 & 8974 & 930 & 18 & - \\
\hline 49 & 752 & 288 & 463 & 6 & - \\
\hline 50 & 551 & 166 & 385 & 5 & - \\
\hline 51 & 3488 & 2054 & 1433 & 11 & - \\
\hline 52 & 2357 & 1277 & 1081 & 8 & - \\
\hline 53 & 686 & 268 & 418 & 4 & - \\
\hline 54 & 8475 & 7992 & 483 & 14 & - \\
\hline 55 & 1117 & 934 & 182 & 7 & - \\
\hline 56 & 290 & 81 & 209 & 4 & - \\
\hline 57 & 162 & 13 & 149 & 1 & - \\
\hline 58 & 1384 & 1201 & 183 & 6 & - \\
\hline 59 & 202 & 24 & 178 & 2 & - \\
\hline 60 & 2252 & 1852 & 400 & 10 & - \\
\hline 61 & 488 & 164 & 324 & 7 & - \\
\hline 62 & 351 & 55 & 296 & 2 & - \\
\hline 63 & 675165 & 675112 & 53 & 24 & São Francisco \\
\hline 64 & 642 & 102 & 540 & 2 & - \\
\hline 65 & 412 & 40 & 372 & 1 & - \\
\hline 66 & 2306 & 1867 & 438 & 5 & - \\
\hline 67 & 311 & 15 & 297 & 1 & - \\
\hline 68 & 3840 & 3605 & 235 & 4 & - \\
\hline 69 & 16907 & 16394 & 513 & 9 & Vaza-Barris \\
\hline 70 & 199 & 58 & 141 & 6 & - \\
\hline 71 & 336 & 72 & 264 & 5 & - \\
\hline 72 & 9148 & 8908 & 240 & 17 & - \\
\hline 73 & 326 & 31 & 295 & 3 & - \\
\hline 74 & 620 & 267 & 352 & 5 & - \\
\hline 75 & 42013 & 41302 & 712 & 15 & Itapicuru \\
\hline 76 & 3050 & 2604 & 446 & 11 & - \\
\hline 77 & 143 & 52 & 91 & 5 & - \\
\hline 78 & 2526 & 2249 & 278 & 7 & - \\
\hline 79 & 107 & 21 & 85 & 2 & - \\
\hline 80 & 4460 & 4366 & 94 & 16 & - \\
\hline 81 & 148 & 83 & 66 & 4 & - \\
\hline 82 & 158 & 110 & 49 & 5 & - \\
\hline 83 & 105 & 63 & 42 & 5 & - \\
\hline 84 & 47 & 29 & 17 & 5 & - \\
\hline 85 & 54 & 32 & 23 & 2 & - \\
\hline 86 & 102 & 15 & 87 & 1 & - \\
\hline 87 & 58053 & 56893 & 1161 & 44 & Paraguaçu \\
\hline 88 & 217 & 31 & 186 & 2 & - \\
\hline 89 & 10068 & 9894 & 175 & 16 & - \\
\hline 90 & 4962 & 4782 & 181 & 15 & - \\
\hline 91 & 2912 & 2133 & 779 & 21 & - \\
\hline 92 & 84 & 17 & 67 & 2 & - \\
\hline 93 & 56051 & 55970 & 82 & 15 & Contas \\
\hline 94 & 68 & 29 & 39 & 3 & - \\
\hline 95 & 188 & 113 & 75 & 6 & - \\
\hline 96 & 40 & 4 & 36 & 1 & - \\
\hline 97 & 30 & 3 & 27 & 1 & - \\
\hline
\end{tabular}


Tab. 1. (continued).

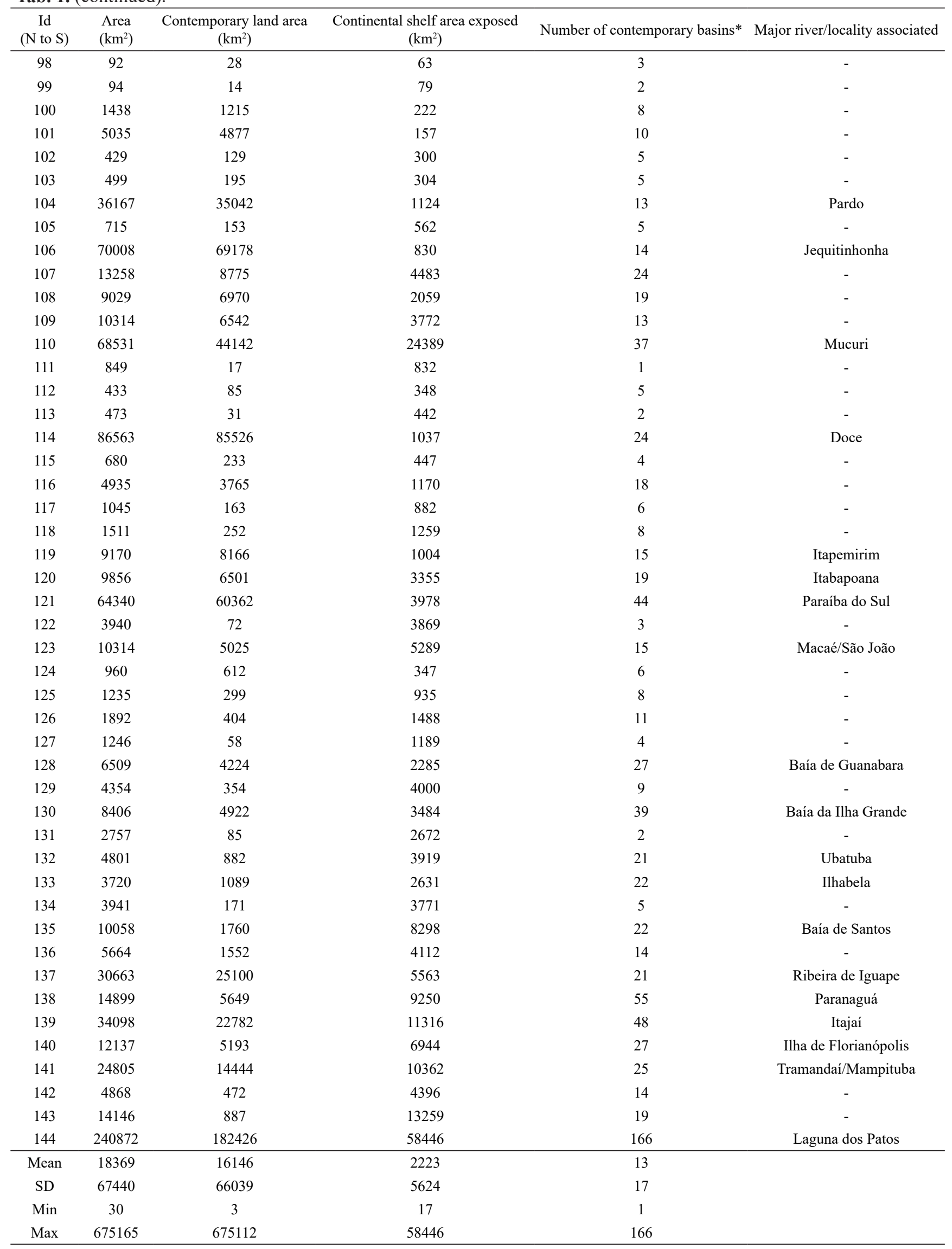


paleodrainages, as in other parts of the world, appear to be impacting the Brazilian ichthyofauna. For example, using a paleodrainage reconstruction for the southeastern coast of Brazil, it was demonstrated that paleodrainages and its properties account for most of the genetic variation and diversity observed for the characid genus Hollandichthys based on mitochondrial DNA (Thomaz et al., 2015) and next generation sequencing data (Thomaz et al., 2017). Likewise, analyses that took into consideration fluctuations on sea level suggests its role in structuring genetic divergence and demographic history of other members of the coastal ichthyofauna (Baggio et al., 2017; Hirschmann et al., 2017; Lima et al., 2017; Ramos-Fregonezi et al., 2017; Tschá et al., 2016, 2017).

Although the inferred paleodrainages provide insights about past connections, we caution that not all connections equally influenced the Brazilian ichthyofauna. For example, differences in the slope along the coast would result in different durations of connections, and the duration of connections can impact divergence patterns (see Papadopoulou, Knowles 2015a,b). In addition, the formation of river connections does not mean that all species of fish would necessarily disperse across them. For example, an interaction between species ecology and the landscape could impact the effectiveness of past connection for dispersal (e.g., differences in dispersal depending on whether the species inhabits lowland areas versus the headwaters; Hirschmann et al., 2015). Consideration of species-specific effects is therefore an important biological component that needs to balance the abiotic factors that are often invoked for explaining divergence patterns (reviewed in Papadopoulou, Knowles, 2016). For example, it is possible that yet unknown river capture events might contribute to divergence patterns that do not exactly match expectations based on paleodrainage boundaries (i.e., "Pattern C" in Ribeiro, 2006; Lima et al., 2017) or when information about paleodrainages is lacking (Ramos-Fregonezi et al., 2017). Other potential explanations could underlie these incongruent patterns, ranging from misplaced interpretations of shared lineage (e.g., incomplete lineage sorting, instead of dispersal, could explain some geographic patterning of lineages, especially for Pleistocene; see Thomaz et al., 2015), to taxonomic differences that influence whether and when species might have dispersed across the past connections associated with paleodrainages (Hirschmann et al., 2015; Thomaz, Knowles, in prep.).

The small and isolated basins along the Brazilian coast have been grouped into biogeographic units based on their shared patterns of ichthyofauna distribution (Géry, 1969; Menezes, 1988; Vari, 1988; Bizerril, 1994; Abell et al., 2008; Lévêque et al., 2008). We note that there is a general correspondence between some paleodrainages and these proposed biogeographic areas. For example, ecoregions such as the Laguna dos Patos and Tramandai-Mampituba sensu Abell et al. (2008) show a high correspondence with the paleodrainages we inferred in these areas. Likewise, for some ecoregions, such as S. Francisco and Parnaiba, the inferred pale- odrainages generally correspond to a single contemporary basin. Although in most cases several paleodrainages occur within a single ecoregion, the number of paleodrainages within an ecoregion varies latitudinally. For example, the south is characterized by relatively small ecoregions with fewer paleodrainages (e.g., Southeastern Mata Atlantica; Ribeira de Iguape ecoregions), whereas the north is characterized by relatively large ecoregions encompassing several current and past rivers (e.g., Northeastern Mata Atlantica; Northeastern Caatinga and Coastal Drainages ecoregions). Since freshwater ecoregions were proposed based on the distributions and compositions of specific groups of the freshwater ichthyofauna (e.g., the genus Trichomycterus, several genera in Neoplecostominae and the presence of killifish; Abell et al., 2008), it is still unclear if biogeographic units delineated based on select taxa will be generally representative of the entire coastal ichthyofauna. In particular, because the groups used to delineate these ecoregions are known for being small range, low dispersal and highly endemic groups, geographic distributional boundaries could differ among taxa with different ecologies. Nevertheless, analyses of endemism along the coast for a large array of freshwater fishes also presented evidence supporting the role of paleodrainage connectivity (e.g., Tramandaí-Mampituba rivers, and Mucuri and São Mateus rivers; Carvalho, 2007; Camelier, Zanata, 2014).

Paleodrainages properties, including the ones inferred here (e.g., area and number of contemporary basins forming a paleodrainage), are known to be good predictors of species richness (Albert et al., 2011; Dias et al., 2014; Tedesco et al., 2005). Given the differences in the properties of paleodrainages, it would be interesting to explore whether the difference in the continental shelf exposure along the coast structures the distribution and divergence patterns of ichthyofauna along the Brazilian coast. In general, currently isolated rivers are hypothesized to have been more connected during the Pleistocene in the southeast, forming large paleodrainages, relative to the northeast (Tab. 1 and Fig. 3). Therefore, the relative contribution of the past, as opposed to contemporary factors in structuring diversity might also differ. For example, although genetic structure among fish populations of southeastern rivers is largely explained by paleodrainages distributions (Thomaz et al., 2015; 2017), this may be a regional phenomenon. More specifically, the contemporary northeastern river basins (encompassing the ecoregions of Northeastern Mata Atlantica - north of Abrolhos Bank, S. Francisco and Northeastern Caatinga \& Coastal Drainages), not the paleodrainages, may best predict patterns of genetic divergence given the limited connectivity promoted among rivers during sea level retreat in this area (Fig. 3).

Conclusions. The inferred paleodrainages represent an application of GIS techniques with tremendous utility in biological study, with the potential to inform conservation strategies. Moreover, these inferences are particularly invaluable to regions where there is a lot of uncertainty about possible past connections among contemporary river basins 
because of limited geologic data. With the incredibly diverse ichthyofauna of the Brazilian coast, and its high levels of endemism, the maps of the inferred paleodrainages provide a backdrop for researchers to test hypotheses about past riverine connectivity. The inferred paleodrainages are based on data that is independent of the biological data, allowing for test of such connections in structuring genetic variation, species divergence and distributions along the Brazilian coast. This is a significant advance over using biological patterns to simply infer past connections or possible biogeographic constraints. Lastly, for the freshwater ichthyofauna of Brazil, tests related to past distributions and possible connections among contemporary isolated river basins provides an important historical dimension for exploring evolutionary processes operating at different spatial and temporal scales that may have contributed to the diversity of freshwater fishes that inhabit coastal basins.

\section{Acknowledgments}

The authors thank the organization committee of the II International Symposium on Phylogeny and Classification of Neotropical Fishes for the invitation to contribute to the special volume, as well as Tiago P. Carvalho (UFRGS) for kindly sharing the fish photographs depicted in Fig. 2. Finally, we thank four anonymous reviewers who provided helpful comments that improved the quality of the manuscript.

\section{References}

Abell R, Thieme ML, Revenga C, Bryer M, Kottelat M, Bogutskaya $\mathrm{N}$ et al. Freshwater ecoregions of the world: a new map of biogeographic units for freshwater biodiversity conservation. BioScience. 2008; 58(5):403-14.

Ab'Saber AN. Megageomorfologia do território brasileiro. In: Cunha SB, Guerra AJT, editors. Geomorfologia do Brasil. Rio de Janeiro: Bertrand; 1998. p.71-106.

Albert JS, Petry P, Reis RE. Major biogeographic and phylogenetic patterns. In: Albert JS, Reis RE, editors. Historical biogeography of Neotropical freshwater fishes. Berkley: University of California Press; 2011. p.21-57.

Albert JS, Reis RE. Introduction to Neotropical Freshwaters. In: Albert JS, Reis RE, editors. Historical biogeography of Neotropical freshwater fishes. Berkley: University of California Press; 2011. p.3-19.

Baggio RA, Stoiev SB, Spach HL, Boeger WA. Opportunity and taxon pulse: the central influence of coastal geomorphology on genetic diversification and endemism of strict estuarine species. J Biogeogr. 2017; 44(7):1626-39.

Bizerril CRSF. Análise taxonômica e biogeográfica da ictiofauna de água doce do leste brasileiro. Acta Biol Leopold. 1994; 16(1):51-80.

Buckup PA. The eastern Brazilian shield. In: Albert JS, Reis RE, editors. Historical biogeography of Neotropical freshwater fishes. Berkley: University of California Press; 2011. 203-10.

Camelier P, Zanata AM. Biogeography of freshwater fishes from the Northeastern Mata Atlântica freshwater ecoregion: distribution, endemism, and area relationships. Neotrop Ichthyol. 2014; 12(4):683-98.
Carvalho TP. Distributional patterns of freshwater fishes in coastal Atlantic drainages of eastern Brazil: a preliminary study applying parsimony analysis of endemism. Darwiniana. 2007; 45(Suppl):65-67.

Carvalho TP, Thomaz AT. Distributional patterns of freshwater fishes in coastal drainages of Atlantic Rain Forest in eastern Brazil. in prep.

Conti LA. Evidências da evolução dos sistemas de paleodrenagens na plataforma continental da região de São Sebastião (litoral norte do estado de São Paulo). Rev Bras Geomorf. 2009; 10(2):45-55.

Conti LA, Furtado VV. Topographic registers of paleo-valleys on the southeastern Brazilian continental shelf. Braz J Oceanogr. $2009 ; 57(2): 113-21$.

Dias MS, Oberdorff T, Hugueny B, Leprieur F, Jézéquel C, Cornu $\mathrm{JF}$ et al. Global imprint of historical connectivity on freshwater fish biodiversity. Ecol. Letters. 2014; 17(9):1130-40.

Fleming K, Johnston P, Zwartz D, Yokoyama Y, Lambeck K, Chappell J. Refining the eustatic sea-level curve since the Last Glacial Maximum using far- and intermediate-field sites. Earth Planet Sci Lett. 1998; 163(1-4):327-42.

Fricke R, Eschmeyer WN, van der Laan R (eds). Catalog of fishes: genera, species, references. [World Wide Web electronic publication]. 2017. [cited 2017 Nov]. Available from: http:// researcharchive.calacademy.org/research/ichthyology/catalog/ fishcatmain.asp

Géry J. The fresh-water fishes of South America. In: Fittkau EJ, Illies J, Klinge H, Schwabe GH, Sioli H, editors. Biogeoraphy and ecology in South America, Volume II. Springer Netherlands, Junk: The Hague. 1969. p.828-48.

Hirschmann A, Fagundes NJ, Malabarba LR. Ontogenetic changes in mouth morphology triggers conflicting hypotheses of relationships in characid fishes (Ostariophysi: Characiformes). Neotrop Ichthyol. 2017; 15(1):e160073. Available from: http:// dx.doi.org/10.1590/1982-0224-20160073

Hirschmann A, Malabarba LR, Thomaz AT, Fagundes NJR. Riverine habitat specificity constrains dispersion in a Neotropical fish (Characidae) along Southern Brazilian drainages. Zool Scr. 2015; 44(4):374-82.

Lévêque C, Oberdorff T, Paugy D, Stiassny MLJ, Tedesco PA. Global diversity of fish (Pisces) in freshwater. Hydrobiologia. 2008; 595(1):545-67.

Lima SMQ, Berbel-Filho WM, Araújo TF, Lazzarotto H, Tatarenkov A, Avise JC. Headwater capture evidenced by paleo-rivers reconstruction and population genetic structure of the armored catfish (Pareiorhaphis garbei) in the Serra do Mar mountains of southeastern Brazil. Front Genet. 2017; 8(199). Available from: http://doi.org/10.3389/fgene.2017.00199

Menezes NA. Implications of the distribution patterns of the species of Oligosarcus (Teleostei, Characidae) from central and southern South America. In: Proceedings of a workshop on neotropical distribution patterns. Rio de Janeiro:Academia Brasileira de Ciências. 1988. p.295-304.

Menezes NA, Ribeiro AC, Weitzman SH, Torres RA. Biogeography of Glandulocaudinae (Teleostei: Characiformes: Characidae) revisited: phylogenetic patterns, historical geology and genetic connectivity. Zootaxa. 2008; 1726:33-48.

Miller KG, Mountain GS, Wright JD, Browning JV. A 180-million-year record of sea level and ice volume variations from continental margin and deep-sea isotopic records. Oceanography. 2011; 24(2):40-53.

Papadopoulou A, Knowles LL. Species-specific responses to island connectivity cycles: refined models for testing phylogeographic 
concordance across a Mediterranean Pleistocene Aggregate Island complex. Mol Ecol. 2015a; 24(2):4252-68.

Papadopoulou A, Knowles LL. Genomic tests of the species-pump hypothesis: Recent island connectivity cycles drive population divergence but not speciation in Caribbean crickets across the Virgin Islands. Evolution. 2015b; 69(6):1501-17.

Papadopoulou A, Knowles LL. Toward a paradigm shift in comparative phylogeography driven by trait-based hypotheses. Proc Natl Acad Sci USA. 2016; 113(29):8018-24.

Pereira TL, Santos U, Schaefer CE, Souza GO, Paiva SR, Malabarba LR et al. Dispersal and vicariance of Hoplias malabaricus (Bloch, 1794) (Teleostei, Erythrinidae) populations of the Brazilian continental margin. J Biogeogr. 2013; 40(5):905-14.

Perron JT, Richardson PW, Ferrier KL, Lapôtre M. The root of branching river networks. Nature. 2012; 492:100-05.

$\mathrm{R}$ Core Team. R: A language and environment for statistical computing. R Foundation for Statistical Computing, Vienna, Austria. URL https://www.R-project.org/. 2017.

Ribeiro AC. Tectonic history and the biogeography of the freshwater fishes from the coastal drainages of eastern Brazil: an example of faunal evolution associated with a divergent continental margin. Neotrop Ichthyol. 2006; 4(2):225-46.

Ramos-Fregonezi AMC, Malabarba LR, Fagundes NJR. Population genetic structure of Cnesterodon decemmaculatus (Poeciliidae): a freshwater look at the Pampa biome in Southern South America. Front Genet. 2017; 8(214). Available from: https://doi.org/10.3389/fgene.2017.00214

Riccomini C, Sant'Anna LG, Ferrari AL. Evolução geológica do rift continental do sudeste do Brasil. In: Mantesso-Neto V, Bartorelli A, Carneiro CDR, Brito-Neves BB, editors. Geologia do continente Sul-Americano: evolução da obra de Fernando Flávio Marques de Almeida. São Paulo: Becca; 2004. p.383-405.

Riccomini C, Grohmann CH, Sant'Anna LG, Hiruma ST. A captura das cabeceiras do Rio Tietê pelo Rio Paraíba do Sul. In: Modenesi-Gauttieri MC, Bartorelli A, Mantesso-Neto V, Carneiro CDR, Lisboa MBAL. A obra de Aziz Nacib Ab'Saber. São Paulo: Becca. 2010. p.157-69.

Roxo FF, Albert JS, Silva GS, Zawadzki CH, Foresti F, Oliveira C. Molecular phylogeny and biogeographic history of the armored Neotropical catfish subfamilies Hypoptopomatinae, Neoplecostominae and Otothyrinae (Siluriformes: Loricariidae). PLOSone. 2014; 9(8):e105564.

Roxo FF, Zawadzki CH, Alexandrou MA, Costa Silva GJ, Chiachio $\mathrm{MC}$, Foresti F et al. Evolutionary and biogeographic history of the subfamily Neoplecostominae (Siluriformes: Loricariidae). Ecol Evol. 2012; 2(10):2438-49.

Saadi A. Neotectônica da plataforma continental brasileira: esboço e interpretações preliminares. Geonomos. 1993; 1(1):1-15.

Strahler AN. Quantitative analysis of watershed geomorphology. EOS Trans Am Geophys Union. 1957; 38(6):913-20.

Tedesco PA, Oberdorff T, Lasso CA, Zapata M, Hugueny B. Evidence of history in explaining diversity patterns in tropical riverine fish. J Biogeogr. 2005; 32(11):1899-907.

Thomaz AT, Malabarba LR, Bonatto SL, Knowles LL. Testing the effect of palaeodrainages versus habitat stability on genetic divergence in riverine systems: study of a Neotropical fish of the Brazilian coastal Atlantic Forest. J Biogeogr. 2015; 42(12): 2389-401.

Thomaz AT, Malabarba LR, Knowles LL. Genomic signatures of paleodrainages in a freshwater fish along the southeastern coast of Brazil: genetic structure reflects past riverine properties. Heredity. 2017; 119(4):287-94.

Thomaz AT, Knowles LL. Spatial and temporal congruence of regional genomic structure across Brazilian coastal fish community. in prep.

Thomaz AT, Knowles LL. Flowing into the unknown: inferred paleodrainages for studying the ichthyofauna of Brazilian coastal rivers - paleodrainages shapefiles [Data set]. University of Michigan Deep Blue Data Repository. 2018; Available from: https://doi.org/10.7302/Z2HH6H8P

Torres RA, Ribeiro J. The remarkable species complex Mimagoniates microlepis (Characiformes: Glandulocaudinae) from the Southern Atlantic Rain forest (Brazil) as revealed by molecular systematic and population genetic analyses. Hydrobiologia, 2008; 617(1):157-70.

Tschá MK, Baggio RA, Marteleto FM, Abilhoa V, Bachmann L, Boeger WA. Sea-level variations have influenced the demographic history of estuarine and freshwater fishes of the coastal plain of Paraná, Brazil. J Fish Biol. 2016; 90(3):968-79.

Tschá MK, Bachmann L, Abilhoa V, Boeger WA. Past connection and isolation of catchments: The sea-level changes affect the distribution and genetic variability of coastal freshwater fishes. Estuarine, Coastal Shelf Sci. 2017; 190:31-9.

Vari RP. The Curimatidae, a lowland Neotropical fish family (Pisces: Characiformes); distribution, endemism, and phylogenetic biogeography. In: Proceedings of a workshop on neotropical distribution patterns. Rio de Janeiro:Academia Brasileira de Ciências. 1988. p. 343-77

Weitzman SH, Menezes NA, Weitzman MJ. Phylogenetic biogeography of the Glandulocaudini (Teleostei: Characiformes, Characidae) with comments on the distributions of other freshwater fishes in eastern and southeastern Brazil. In: Proceedings of a workshop on neotropical distribution patterns. Rio de Janeiro:Academia Brasileira de Ciências. 1988. p.79427.

Willett SD, McCoy SW, Perron JT, Goren L, Chen CY. Dynamic reorganization of river basins. Science. 2014; 343(6175). Available from: http://dx.doi.org/10.1126/science.1248765

Zalán PV, Oliveira JAB. Origem e evolução estrutural do Sistema de Riftes Cenozóicos do Sudeste do Brasil. Boletim de Geociencias da PETROBRAS. 2005; 13(2):269-300.

Zamudio KR, Robertson JM, Chan LM, Sazima I. Population structure in the catfish Trichogenes longipinnis: drift offset by asymmetrical migration in a tiny geographic range. Biol J Linnean Soc. 2009; 97(2):259-74.

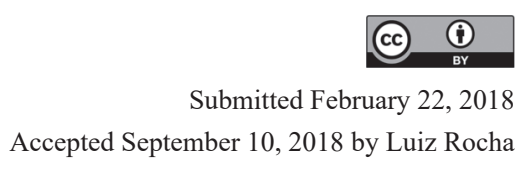

